\title{
Internet projects in the formation of professional competences in students
}

\section{Proyectos de internet en la formación de competencias profesionales en los estudiantes}

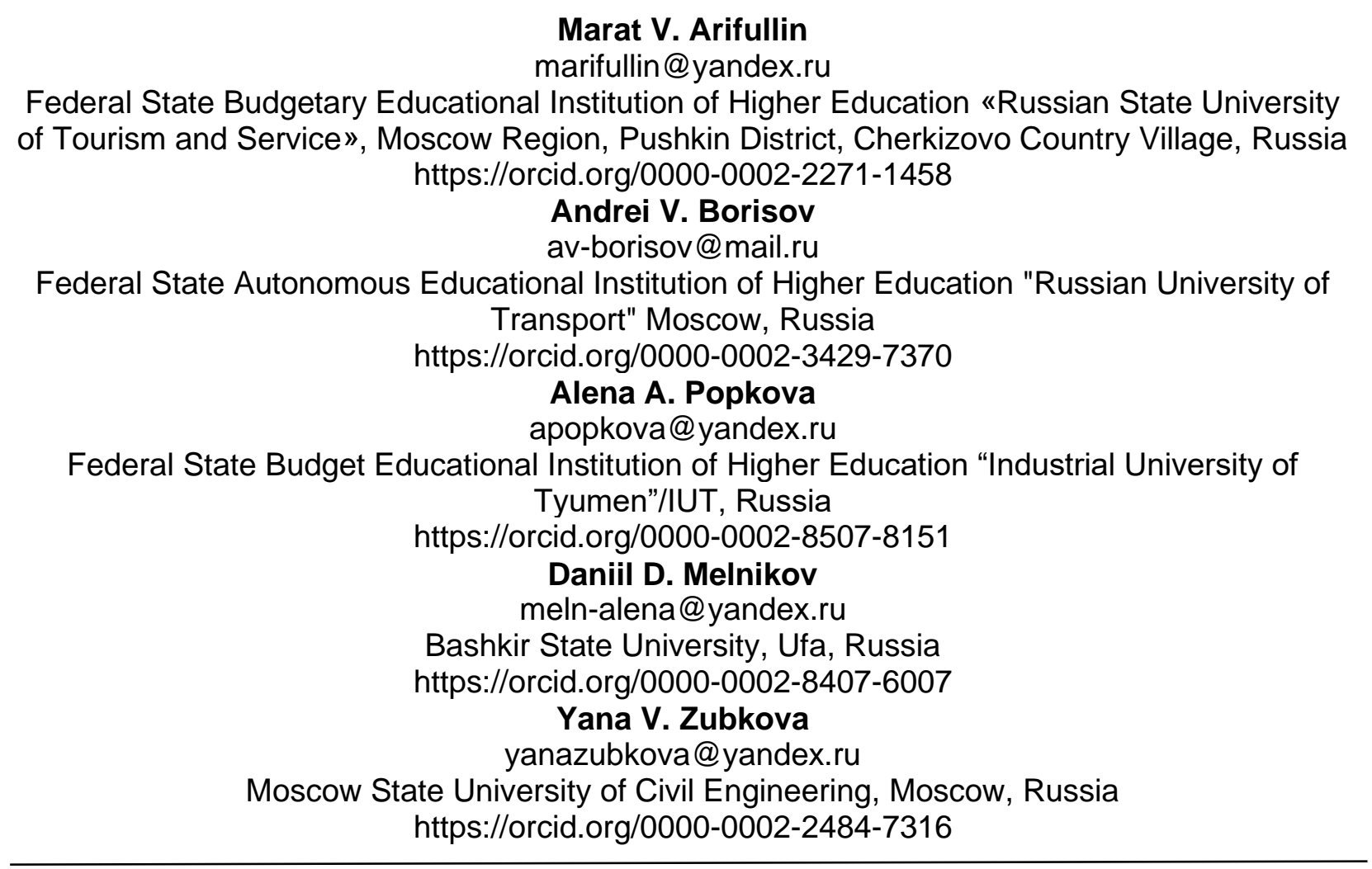

Recibido: 21/12/2020

Aceptado: 22/01/2021

\begin{abstract}
The purpose of the article was to carry out an analysis of the experience of implementing Internet projects in the formation of the professional competence of students. The study involved 154 students aged 20 to 23 years. The article reveals the scale of general self-efficacy of R. Schwarzer and M. Erusalem and the Karpov reflexivity questionnaire as methods that allow determining the student's ability to independently navigate in conditions of uncertainty and solve professional problems, correct their actions to achieve the best result. The effectiveness of the Internet design
\end{abstract}


of students of higher educational institutions was calculated as a percentage of the maximum possible result.

Key Words: internet design, vocational training, higher education institution, project, professional competence, electronic technology.

\section{Resumen}

El Objeto del artículo fue realizar un análisis de la experiencia de implementación de proyectos de Internet en la formación de la competencia profesional de los estudiantes. El estudio involucró a 154 estudiantes de entre 20 y 23 años. El artículo revela la escala de autoeficacia general de R. Schwarzer y M. Erusalem y el cuestionario de reflexividad de Karpov como métodos que permiten determinar la capacidad del estudiante para navegar de forma independiente en condiciones de incertidumbre y resolver problemas profesionales, corregir sus propias acciones para lograr el mejor resultado. La efectividad del diseño de Internet de los estudiantes de las instituciones de educación superior se calculó como un porcentaje del resultado máximo posible.

Palabras clave: diseño de Internet, formación profesional, institución de educación superior, proyecto, competencia profesional, tecnologías electrónicas.

\section{Introduction}

The development of technological progress and the transition to the widespread use of Internet technologies leads to the introduction of electronic tools in the field of vocational education. The Internet is used as a platform for implementing students ' creative ideas (Vaganova et al., 2020a). The use of Internet technologies allows you to fill the development of students with new content and quickly introduce Internet projects to the masses. At the same time, it is possible to quickly assess the interest of users in particular development (Sergeeva et al., 2019).

Internet projects allow students to reveal their professional position, to show their formed competencies (Bogdanova et al., 2019).

Projects are relevant tools in professional and pedagogical training, which contribute to the formation of students ' ability to predict, plan, analyze, and synthesize information. The project activity involves both individual and group work, so it allows you to develop communication skills, stimulates search and creative activity, and initiative (Mazanyuk et al., 2020). The project is one of the most effective ways to form professional competence (Vaganova et al., 2020b). An important part of the project activity is Internet projects that allow students to apply their knowledge in practice (Rudenko et al., 2021). In the process of implementing Internet projects, students form an independent, creative position. They have the opportunity to put their ideas into practice (Dobudko et al., 2019b). The development of Internet design will allow you to develop the ability to reflect, professional self-realization (Syrina et al., 2020). 


\section{Theoretical framework}

Each Internet project is a creative product, the creation of which is carried out in pairs or small groups.

As organizational conditions for the implementation of Internet design technology, V. K. Obydenkova highlights the phased nature of the Internet design process; the orientation of the Internet design process to the formation of professional competencies of students; the orientation of students to the professional use of the Internet (implies a change in the motives for using the Internet by students, the essence of which is constant professional self-improvement) (Obydenkova, 2017).

Among the main stages, the author distinguishes the first (preparatory); the second (introductory), the third (indicative), the fifth (activity) and the sixth (evaluative-reflexive) (lliyazova, 2020).

The table shows the forms of interaction of students in the process of implementing an Internet project.

Table 1. Forms of interaction between students in the process of implementing an Internet project

\begin{tabular}{ll}
\hline \multicolumn{1}{c}{ Form } & \multicolumn{1}{c}{ Types of classes } \\
\hline Full-time & Seminars, interactive lectures, consultations, master classes, trainings \\
\hline Distance & $\begin{array}{l}\text { Online consultations with teachers in real time, webinars and video } \\
\text { conferences }\end{array}$ \\
\hline
\end{tabular}

Teachers provide consulting support both in-person and online (Kamenkova et al., 2015).

The authors distinguish the following principles of Internet design: regularity (compliance with the time frame and structure of the project judgment) (Smirnova et al., 2019); inclusiveness (involvement of all participants and each individual in the project implementation); the principle of dialogically (preservation of subject-subject relations between the teacher and the student); problematic (the teacher or the project supervisor sets students problem tasks aimed at activating the processes of understanding the ways to solve them by each student in the team); reflection (creating conditions for students to evaluate their performance and work on mistakes) (Yarygin et al., 2019a).

M. V. Yarmolinskaya reveals the Internet project as a flexible pedagogical tool that can be presented in various ways of organizing and conducting (Yarmolinskaya, 2016).

Internet projects can include any projects related to the use of the Internet (Dobudko et al., 2019a). Internet projects created on the Internet and implemented in the same 
space (for a specific audience of users) and Internet projects implemented using the Internet can be distinguished (Yarygin et al., 2019b).

These can be independent Internet resources (websites, blogs, social media communities, and other developments) and events that can be held in reality (Kidina, 2020).

The characteristics of an Internet project include the presence of a specific topic; a professional problem that needs to be solved; systematic content and step-by-step implementation of actions; consistency; relevance of ideas (Ponachugin et al., 2019).

\section{Methodology}

The study involved students aged 20 to 23 years in the number of 154 people. They were randomly assigned to micro groups (22 groups of 7 people each).

The following techniques were used. Since reflection is one of the most important elements in the implementation of the project, the Karpov reflexivity questionnaire was used. The questionnaire is aimed at determining the level of development of reflection in the individual. Students were asked to give answers to 27 questions (to express the degree of agreement) on a scale of seven options (1-absolutely disagree; 2 -disagree; 3rather agree; 4 - do not know (I cannot decide); 5 - rather agree; 6 - agree; 7 - full agreement. As a result, the following types of reflection are revealed situational, retrospective, and prospective reflection.

A fragment of the questionnaire is presented in the table.

Table 2. Fragment of the Karpov reflection test

\begin{tabular}{ll}
\hline Statement & $\begin{array}{l}\text { Answer } \\
1 \text { point -absolutely disagree; } \\
2 \text { points - disagree; 3 points-rather agree; } 4 \text { points - } \\
\text { don't know (can't decide); } 5 \text { points - rather agree; } 6 \\
\text { points - agree; 7 points - absolutely agree. }\end{array}$ \\
\hline $\begin{array}{l}\text { After reading a good book, I want to } \\
\text { discuss it with someone and I think } \\
\text { about its meaning for a long time }\end{array}$ & $1-7$ \\
\hline $\begin{array}{l}\text { When someone asks me something } \\
\text { unexpectedly, I can answer the first } \\
\text { thing that comes to mind }\end{array}$ & $1-7$ \\
\hline $\begin{array}{l}\text { Before I answer the phone, I usually } \\
\text { plan a phone conversation }\end{array}$ & $1-7$ \\
\hline $\begin{array}{l}\text { When I made a mistake, I think } \\
\text { about it for a long time }\end{array}$ & \multicolumn{1}{l}{$1-7$} \\
\hline
\end{tabular}


The study involved the scale of general self-efficacy of R. Schwarzer and M. Erusalem. The question of self-efficacy in the formation of professional competence of students is of high importance, since through it the student independently builds his behavior by the situation, determines the most effective ways of action to achieve higher results. Selfefficacy is determined, among other things, by confidence in one's actions, which appears due to the formation of professional competence.

The table shows the scale of overall self-efficacy (R. Schwarzer and M. Rrusalem) (Schwarzer et al., 1996).

Table 3. Overall self-efficacy scale

\begin{tabular}{ll}
\hline Statement & $\begin{array}{l}\text { Answer } \\
\text { 1 point -absolutely not true; } \\
2 \text { points - rather not true than true; 3 points- } \\
\text { rather true than not true; 4 points-absolutely } \\
\text { true }\end{array}$ \\
\hline $\begin{array}{l}\text { I can always find solutions to complex } \\
\text { problems if I put in the effort }\end{array}$ & $1-4$ \\
\hline $\begin{array}{l}\text { If something bothers me, I still find a way } \\
\text { out of this situation }\end{array}$ & $1-4$ \\
\hline I manage to achieve my goals quite easily & $1-4$ \\
\hline I know how to handle unusual situations & $1-4$ \\
\hline $\begin{array}{l}\text { I am confident that I can handle the sudden } \\
\text { difficulties that have arisen }\end{array}$ & $1-4$ \\
\hline $\begin{array}{l}\text { If I put in enough effort, I can handle any } \\
\text { situation }\end{array}$ & $1-4$ \\
\hline $\begin{array}{l}\text { I am ready for any difficult situations, } \\
\text { because I rely only on my strength }\end{array}$ & $1-4$ \\
\hline $\begin{array}{l}\text { I usually find several solutions to the } \\
\text { problem }\end{array}$ & $1-4$ \\
\hline $\begin{array}{l}\text { I can find a solution even in seemingly } \\
\text { I'm usually able to keep things under } \\
\text { control }\end{array}$ & $1-4$ \\
\hline
\end{tabular}

Low self-efficacy - 19 points or less, below average-20-24, average-25-29, 30-35-above average, high self-efficacy-36-40.

The effectiveness of Internet design was calculated as a percentage of the maximum possible result. 


\section{Results and discussion}

Internet design in higher education institutions is carried out using various electronic tools. The project curator can interact with both one and several groups (Pichugina, Bondarchuk, 2019). The project curator interacts with students both in-person and remotely. There are also opportunities for individual consultation with the leaders of each group who represent common interests (Misakov et al., 2019).

We have identified three stages of Internet design: the initial (indicative), the activity stage, the stage of presenting results and conducting reflection (Bulaeva et al., 2018).

At each stage of the Internet project implementation, all persons interested in the project (partners, representatives of the target audience, and others) are involved in the discussion (Kudinova et al., 2020).

During the implementation of the project, students formulate its name; make a brief description, the essence and goals of the project; choose ways to attract the target audience to the final product (Tsarapkina et al., 2021).

Students are engaged in the development and search for relevant content, determine for themselves whether the project meets the stated goal, whether the project participants perform their functions, whether they are satisfied with their assigned roles (Demidov et al., 2019).

After receiving the first results, students determine whether adjustments to the original project idea are necessary (Shcerbakova et al., 2019). Checking the content of the Internet project is carried out both in the process of independent work, and with the help of a teacher. Showing cognitive flexibility and the ability to respond quickly to changing environmental circumstances, students changed the target audience and the content of the project for more relevant tasks.

Intermediate results were recorded through online consultations with the teacher. The defense of the projects was conducted with an oral retrospective interview with the project groups and with individual students.

The best projects got the opportunity to participate in hackathons, where students improved their product. The hackathon allows students to develop not only the subject skills that are in demand in Data Science, but also soft skills - communication and organizational, which generally contribute to the formation of professional competence at a new level. The hackathon allows you to make the developed Internet project popular. Students can form not only theoretical knowledge, but also gain real practical experience. Each team is controlled by 2 people (project managers), who are responsible for quality control of the received product, its relevance, as well as planning and distribution of responsibilities within each team. 
The figure shows an online consultation session with a teacher on correcting the content of an Internet project.

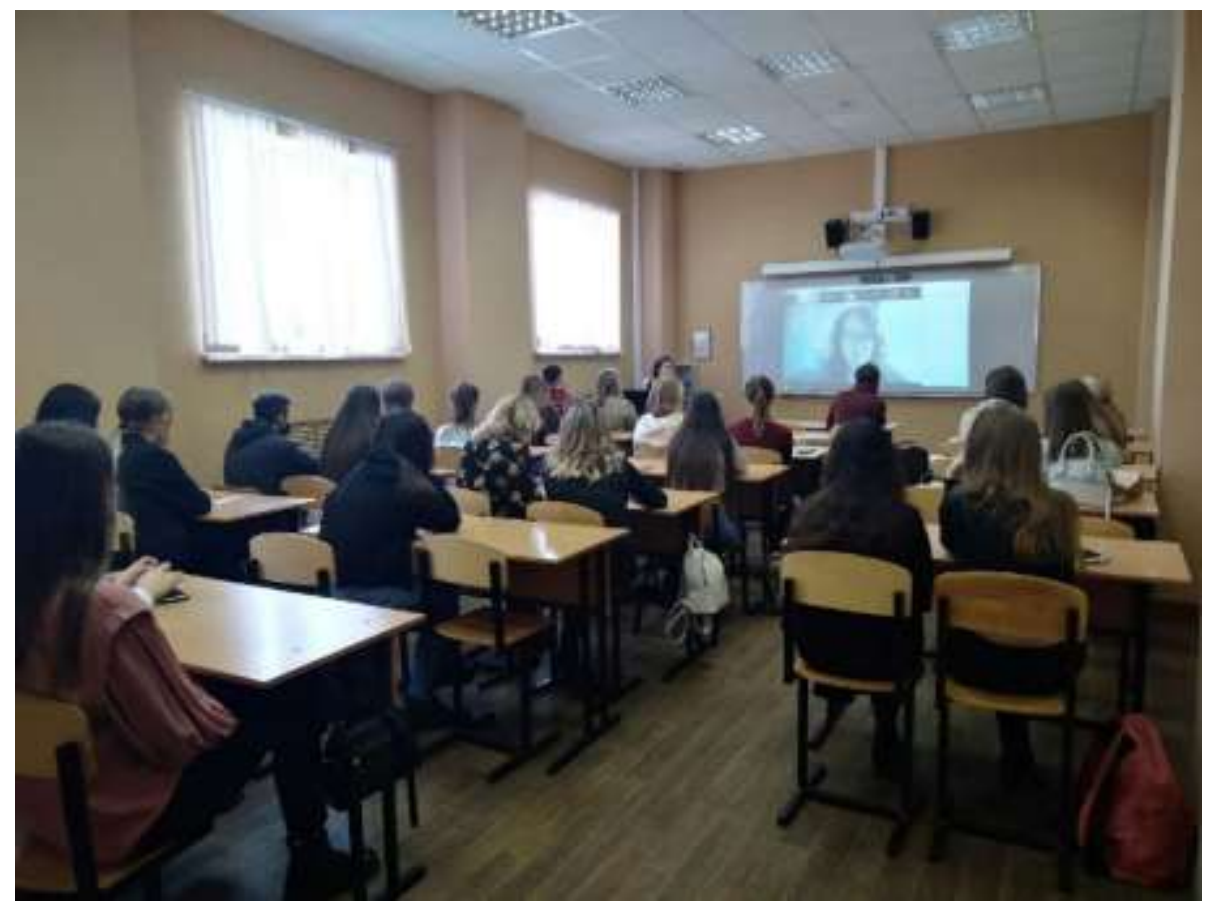

Fig. 1. Online consultation session with Internet design participants

Reflection is a significant element both in the creation of an Internet project and in the implementation of future professional activities in general. In the study among students, the Karpov reflection questionnaire was used. Among the results, the situational type of reflection, retrospective and prospective was noted. Students exercise direct control of behavior in actual situations, analyze the situation and coordinate actions by the circumstances and their state. Among students, there is also an ability to analyze past events, identify the causes of what happened. Students are able and ready for careful planning and analysis of upcoming activities.

The scale of general self-efficacy was also used, which allowed us to identify the growth of professional competence formation, since students actively navigate in professional situations organized both in higher education institutions and at hackathons.

The effectiveness of Internet design was calculated as a percentage of the maximum possible result. The figure shows the effectiveness of Internet design at each stage of Internet design. 


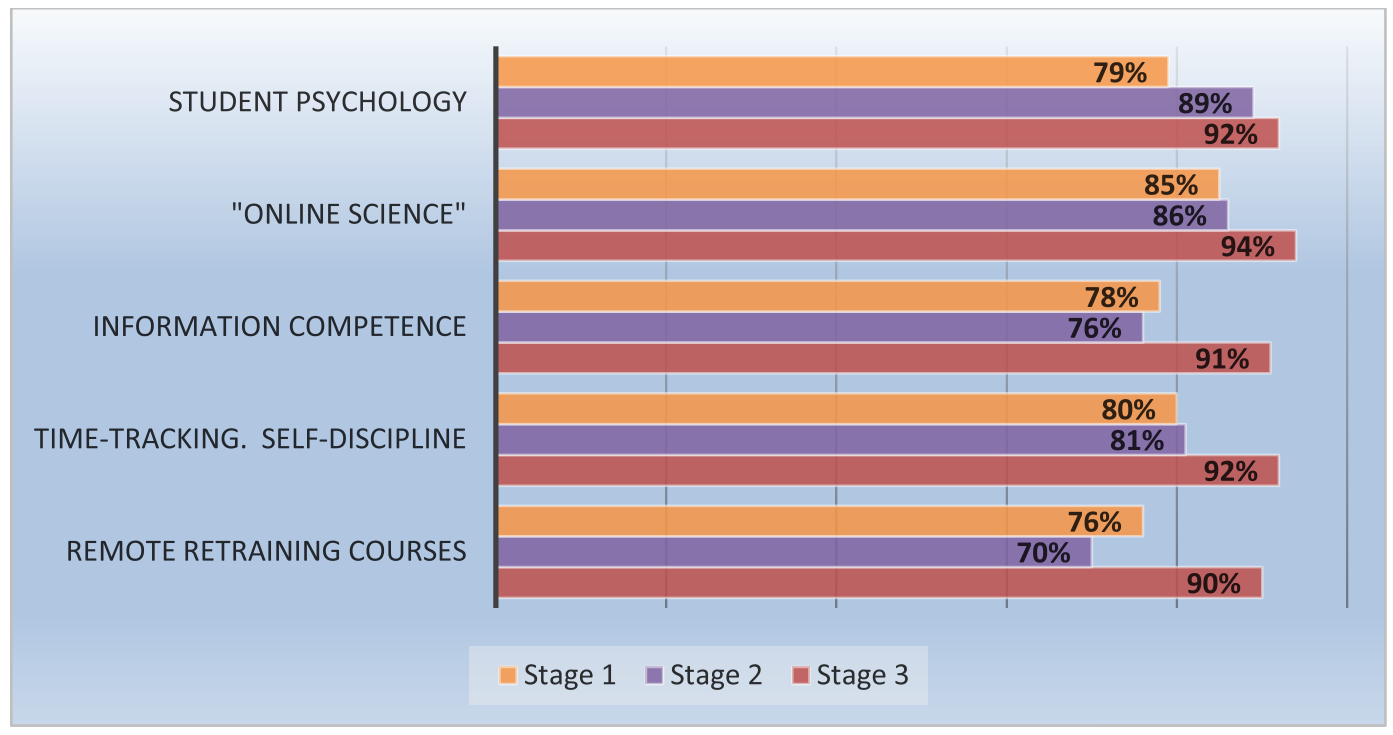

Fig. 2. Results of the evaluation of the leading projects

Out of the total number of participating projects, the experts selected several of the most competitive ones. Most of the participating groups in Internet design show high results at every stage of design.

Figure 3 shows an analysis of the activities of Internet project participants for the period from 2018 to 2020 (the number of projects that entered the international competition level out of the total number of projects).

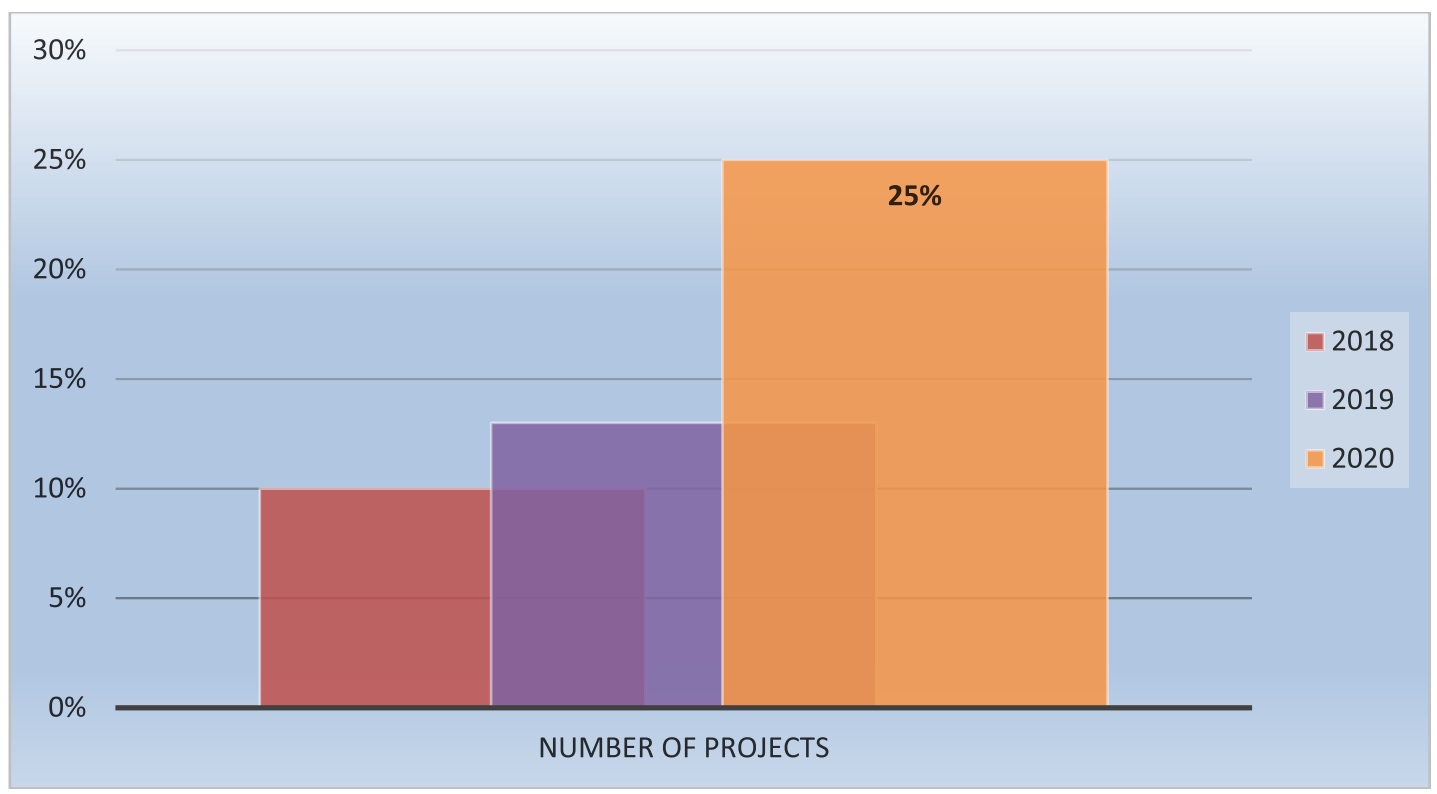

Fig. 3. The number of Internet projects that have reached the international level, as a percentage (2018-2020) 
By 2020, the number of groups of students with relevant high-quality Internet projects that can interest a wide audience has increased. Among such projects, e-learning courses developed to improve the quality of the educational process are of great importance. By developing such courses, students actively improve their professional competence.

\section{Conclusions}

The involvement of students in Internet design has had a positive impact on the reflective processes of students, the assessment of their professional competencies. Students show a willingness to carry out their professional activities.

In the process of implementing Internet projects, students develop the ability to cooperate, to communicate effectively, both orally and in writing, to quickly and independently solve professional problems and to reflect on each stage of their activities. Having gained experience in Internet design, students can independently organize and manage other projects.

The results of the study indicate that Internet design allows students to develop a creative position, implement their ideas and gain additional practical experience, improving their professional competence.

\section{References}

Bogdanova, A.V., Korostelev, A.A., Mukhutdinov, R.H., Shakirova, I.A., Maseleno, A. (2019). Formulation of the problem of mathematical modeling of accommodation of basic stations of cellular communication in residential territories for students of it-directions of preparation. International Journal of Recent Technology and Engineering, 2019, 7(6), Pp. 87-90.

Bulaeva, M. N., Vaganova, O. I; Koldina, M. I., Lapshova, A. V., Khizhnyi, A.V. (2018). Preparation of Bachelors of Professional Training Using MOODLE. Advances in intelligent systems and computing, 622, Pp. 406-411.

Demidov, A., Melnikov, T. Moskvina, A. Tretyakov A. (2019). The Organization of Ecological Education of Per-school Children by Means of Media Literacy Education: Theory, National Policy, Scientometrics and Vectors of Development. Media Education (Mediaobrazovanie), 4, Pp. 470-481.

Dobudko T.V., Korostelev A.A., Gorbatov S.V., Kurochkin A.V., Akhmetov L.G. (2019a). The organization of the university educational process in terms of digitalization of education. Humanities and Social Sciences Reviews. 7(4), Pp. 1148-1154.

Dobudko T.V., Korostelev A.A., Pugach O.I., Ippolitova N. V., Khayrullina R.G., Sitdikov F.F. (2019b). Training of pedagogical education masters: Practice-oriented model. Humanities and Social Sciences Reviews. 7(4), Pp. 1155-1159.

lliyazova A. R. (2020). Learning through cooperation: brain-to-brain communication. Balkan Scientific Review. 4, 2(8), 9-11. 
Kamenkova N. G., Larionova K.A. (2015). Use of electronic educational resources in the process of formation of computational skills of younger school children. Herzen's readings. Primary education. 6 (2). Pp. 175-187.

Kidina L. M. (2020). Management of the pedagogical collective in the conditions of implementing distance learning. Baltic Humanitarian Journal. (Baltic Humanitarian Journal). Vol. 9 No 4 (33), Pp. 93-96.

Kudinova, G., Korostelev, A., Rozenberg, A., Tkachev, B., Vorokova, N. (2020). Sustainable development, green economy - ways of implementation in Russia: regional aspecto. Cuestiones Políticas. 37. 264-276.

Mazanyuk, E.F., Tretyakov, A.L., Amichba, L.R. (2020). Game technologies as a tool of motivation and improvement the quality of university students' training. SHS Web of Conferences: International Scientific and Practical Conference «Teacher Professionalism: Psychological and Pedagogical Support of a Successful Career», Vol. 87.

Misakov, V., Tsurova, L., Yandarbayeva, L., Tkhamadokova, I., \& Gapurovna, G. (2019). Certification of a regional economic complex as a highly effective tool for analysis and diagnostics of its development. Amazonia Investiga, 8(20), 451-458. https://amazoniainvestiga.info/index.php/amazonia/article/view/174

Obydenkova V. K. (2017). Internet design as a tool professional training of students pedagogical universities. Moscow Pedagogical State University. PhD thesis. Moscow.

Pichugina, G.A., Bondarchuk, A.I. 2019. "Structure of the training case in the organization of the educational process". In: Humanitarian Balkan Research. Vol. 2, No. 4, pp. 5-7.

Ponachugin, A.V; Lapygin, Yu.N. 2019. "Digital educational resources of the university: design, analysis and expertise". In: Vestnik Mininskogo universiteta (Vestnik of Minin University). Vol. 7 (2), 5. (in Russ)

Rudenko, I. V., Bystrova, N. V., Smirnova, Zh. V., Vaganova, O. I., Kutepov, M. M. (2021). Modern technologies in working with gifted students. Propositos y representaciones, 9. № SI, Article number e818.

Schwarzer, R., Erusalem, M., Romek, V. (1996). Russian version of the scale of general self-efficiency by R. Schwarzer and M. Erusalem. Foreign psychology, 7, 71-76.

Sergeeva, M., Bondarenko, N., Shebzuhova, T., Solovyov, B., Parinov, D., Shvedov, L., \& Ovchinnikov, A. (2019). Verification of management-support of professional and educational trajectory of students in the socio-cultural educational environment of the university. Amazonia Investiga, 8(18), 5-14. https://amazoniainvestiga.info/index.php/amazonia/article/view/251

Shcerbakova E.V., Shcerbakova T. N. (2019). Experience of use of remote computer technologies at the organization of independent work of students in the conditions of a mark and rating system. Baltic Humanitarian Journal. (Baltic Humanitarian Journal). Vol. 8, No 4 (29), Pp. 192-195.

Smirnova, Z., Kamenez, N., Vaganova, O., Kutepova, L., \& Vezetiu, E. (2019). The experience of using the webinar in the preparation of engineering specialists. Amazonia Investiga, 8(18), 279-287. https://amazoniainvestiga.info/index.php/amazonia/article/view/307 
Syrina, T.A., Demidov, A.A., Tretyakov, A.L. (2020). Development of Digital Skills and Media Education System: From the Organization of Environmental Education of Preschool Children to the ICT Competence of Teachers. Media Education (Mediaobrazovanie), 1, 11-23.

Tsarapkina, J. M., Plahina, L. N., Konoplyuk, N. V., Vaganova, O. I., Lapshova, A. V. (2021). The formation of bachelors' digital competencies at the university. Propositos y representaciones, 9, № SI, Article number e811.

Vaganova, O. I. Korostelev, A. A., Chelnokova, E.A., Bugoslavskaya, A.V. (2020b). Technology for compiling supporting abstracts in the organization of students' independent work. Revista Amazonia Investiga. 9. 376-382.

Vaganova, O., I; Vinnikova, I. S.; Sundeeva, L. A.; Kutepov, M. M.; Popkova, A. A. (2020a). "Development of professional-pedagogical focus of a teacher in vocational training" In: Amazonia Investiga. Vol. 9 No. 25, Pp. 350-355. https://amazoniainvestiga.info/index.php/amazonia/article/view/1079

Yarmolinskaya M.V. (2016) Internet project as a tool for the formation of the responsibility of an older teenager. Herzen university. PhD thesis. St. Petersburg.

Yarygin O.N., Korostelev A.A, Mukhutdinov R.H., Maseleno A. (2019b). Elections and russian citizens residing overseas: Prospects for internet voting. International Journal of Recent Technology and Engineering, 7(6), Pp. 52-57

Yarygin O.N., Korostelev A.A., Akhmetov, L.G., Maseleno, A. (2019a). Modeling of competence as a tool of goal setting for education in modern society. International Journal of Recent Technology and Engineering, 7(6), Pp. 72-77. 